\title{
Comparison Between Angiotensin-Converting Enzyme Inhibitors and Angiotensin Receptor Blockers in Patients with Unstable Angina with Preserved Left Ventricular Systolic Function
}

\author{
Jiong Xiao \\ TEDA International Cardiovascular Hospital \\ Lin-Ze Liu \\ TEDA International Cardiovascular Hospital \\ Wen-Hua Lin ( $\sim$ linwernhua@sina.com ) \\ TEDA International Cardiovascular Hospital
}

\section{Research Article}

Keywords: Angiotensin-converting enzyme inhibitor, Angiotensin receptor blocker, Unstable angina, Left ventricular systolic function, Percutaneous coronary intervention

Posted Date: November 18th, 2021

DOI: https://doi.org/10.21203/rs.3.rs-1076002/v1

License: (c) (1) This work is licensed under a Creative Commons Attribution 4.0 International License.

Read Full License 


\section{Abstract \\ Background}

We investigated the clinical results of angiotensin-converting enzyme inhibitors (ACEls) or angiotensin receptor blockers (ARBs) treatment in patients with unstable angina (UA) with preserved left ventricular systolic function who underwent percutaneous coronary intervention (PCl) due to uncertainty regarding the long-term prognosis using ACEls or ARBs.

\section{Methods}

A total of 1627 UA patients with preserved left ventricular systolic function who successfully underwent $\mathrm{PCl}$ were enrolled. We classified those patients into two groups: the ACEI group $(n=918)$ and the ARB group $(n=709)$ based on discharge medications. The primary endpoint was the incidence of major adverse cardiovascular and cerebrovascular events (MACCEs), including all-cause death, nonfatal myocardial infarction (MI), stroke and target vessel revascularization (TVR), with a follow-up period of 13 months. The secondary endpoint was the occurrence of separate components of MACCEs. We applied the Kaplan-Meier method to depict survival curves, while intergroup differences were performed using the log-rank test. Multivariable Cox regression analysis was applied to assess the prognostic influence of various factors. To balance potential confounding biases derived from differences in baseline levels, propensity score matching (PSM) was used to adjust for confounders between the ACEI and ARB groups.

\section{Results}

After PSM, 660 pairs in each group were created. There were no differences in MACCEs (HR=0.860, 95\%Cl: 0.465-1.590, $P=0.630)$, all-cause death (HR=0.334, 95\%Cl: 0.090-1.238, $P=0.101)$, non-fatal MI (HR=4.929, 95\%Cl: 0.576-42.195, $P=0.145)$, stroke (HR=1.049, 95\%Cl: 0.208-5.290, $P=0.954)$ and TVR $(\mathrm{HR}=1.276,95 \% \mathrm{Cl}: 0.537-3.031, P=0.581)$ between the ACEl and ARB groups.

\section{Conclusions}

Prognoses were comparable between ACEI or ARB treatment in UA patients who had preserved left ventricular systolic function after $\mathrm{PCl}$.

\section{Background}

Unstable angina (UA) is a common type of acute coronary syndrome (ACS) with severe conditions and rapid progression ${ }^{[1]}$. In recent decades, percutaneous coronary intervention $(\mathrm{PCI})$ has been a main treatment technique for $\mathrm{UA}^{[2]}$. However, optimal therapeutic drugs remain the cornerstone of treatment in 
patients with UA even in the present $\mathrm{PCl}$ age group ${ }^{[3]}$. Angiotensin-converting enzyme inhibitors (ACEIs) can decrease mortality and the risk of myocardial infarction in patients who have left ventricular systolic dysfunction ${ }^{[4-6]}$. The European guidelines recommend that ACEls are suitable for UA patients with heart failure with left ventricular ejection fraction (LVEF) $<40 \%$ unless contraindicated, while angiotensin receptor blockers (ARBs) are an alternative for those who are intolerant to ACEIs ${ }^{[7]}$.

However, there is a paucity of comparisons with regard to long-term use of ACEI or ARB therapy in UA patients. Consequently, we compared 13-month clinical outcomes between ACEI or ARB treatment in UA patients undergoing successful PCl with preserved left ventricular systolic function.

\section{Material And Methods}

\section{Study Population and Design}

A total of 3812 coronary heart disease (CHD) patients who underwent successful PCI at TEDA International Cardiovascular Hospital from October 2016 to September 2017 were enrolled. We made these exclusion rules:

(1) Stable CHD ( $n=338,8.9 \%)$;

(2) Myocardial infarction ( $\mathrm{n}=890,23.3 \%)$;

(3) Follow-up loss ( $n=224,5.9 \%)$;

(4) Patients who had not been treated with ACEls or ARBs at discharge $(n=689,18.1 \%)$;

(5) Patients with LVEF『40\%( $n=44,1.2 \%)$.

Ultimately, 1627 UA patients who had preserved left ventricular systolic function after PCI were included. We allocated those patients into two groups, the ACEI group $(n=918,56.4 \%)$ and the ARB group $(n=709$, 43.6\%), based on the use of ACEls or ARBs at discharge (Fig. 1). This research was granted by the ethics committee of TEDA International Cardiovascular Hospital and was conducted according to the Declaration of Helsinki. After discharge, follow-up of the 1627 patients was carried out by clinic visits, readmission, or telephone at 13 months.

\section{PCI Procedure and Medical Treatment}

Coronary angiography (CAG) and $\mathrm{PCl}$ were performed through standard radial or femoral approaches. All patients were given a loading dose of aspirin $300 \mathrm{mg}$ and clopidogrel $300 \mathrm{mg}$ or ticagrelor $180 \mathrm{mg}$ preprocedurally. After discharge, all patients were advised to continue taking medications following their hospital stay, including dual antiplatelet aggregation treatment, beta-blockers, lipid-lowering medication, and ACEls or ARBs. In particular, dual antiplatelet aggregation treatment (aspirin $100 \mathrm{mg}$ daily and clopidogrel $75 \mathrm{mg}$ daily or ticagrelor $90 \mathrm{mg}$ twice a day) was recommended for at least 1 year. 


\section{Study Definitions and Clinical Outcomes}

Unstable angina was defined as myocardial ischaemia in a resting state or on minuscule exertion in the absence of cardiomyocyte damage or necrosis ${ }^{[7]}$. The primary endpoint was the incidence of major adverse cardiovascular and cerebrovascular events (MACCEs), including all-cause death, nonfatal myocardial infarction (MI), stroke and target vessel revascularization (TVR), with a follow-up period of 13 months. The secondary endpoint was the occurrence of separate components of MACCEs (all-cause death, nonfatal MI, stroke and TVR).

\section{Statistical Analysis}

Continuous variables are presented as the mean values \pm standard deviations, and intergroup differences were compared using independent-samples $t$ tests. Categorical variables are presented as numbers (percentages), and intergroup differences were assessed by the chi-square test. We applied the KaplanMeier method to depict survival curves, while intergroup differences were performed using the log-rank test. Multivariable Cox regression analysis was applied to assess the prognostic influence of various factors. To balance potential confounding biases derived from differences in baseline levels, propensity score matching (PSM) was used to adjust for confounders between the ACEI and ARB groups. We assessed all covariates regarded as potentially relevant, including demographics, previous medical history, laboratory indicators, discharge medication and coronary angiography characteristics. PSM was conducted by 1:1 nearest-neighbour matching with a calliper of 0.02. After PSM, 660 pairs in each group were created. We applied multivariable Cox regression analysis to calculate the hazard ratio (HR) and $95 \%$ confidence interval $(\mathrm{Cl})$ in PSM patients. A $P$ value $<0.05$ (bilateral) was considered statistically significant. All data analysis was performed using SPSS software, version 26 (IBM, New York).

\section{Results}

\section{Baseline clinical and coronary angiography characteristics}

Among the 1627 UA patients undergoing successful PCI with preserved left ventricular systolic function, 918 patients $(56.4 \%)$ were treated with ACEls, and 709 patients $(43.6 \%)$ were treated with ARBs at the time of discharge. Table 1 displays the demographics, laboratory indicators, discharge medication and coronary angiography characteristics between the two groups. 
Table 1

Baseline clinical and coronary angiography characteristics

\begin{tabular}{|c|c|c|c|c|c|c|}
\hline \multirow[t]{2}{*}{ Variables } & \multicolumn{3}{|l|}{ All patients } & \multicolumn{3}{|c|}{$\begin{array}{l}\text { Propensity score matching } \\
\text { patients }\end{array}$} \\
\hline & $\begin{array}{l}\text { ACEI } \\
(n=918)\end{array}$ & $\begin{array}{l}\text { ARB } \\
(n=709)\end{array}$ & $P$ & $\begin{array}{l}\text { ACEI } \\
(n=660)\end{array}$ & $\begin{array}{l}\text { ARB } \\
(n=660)\end{array}$ & $\mathbf{P}$ \\
\hline Age (years) & $62.5 \pm 9.1$ & $63.2 \pm 9.3$ & 0.120 & $63.1 \pm 9.0$ & $63.0 \pm 9.4$ & 0.940 \\
\hline Men, n (\%) & $561(61.1)$ & $408(57.5)$ & 0.146 & $389(58.9)$ & $384(58.2)$ & 0.780 \\
\hline BMI $\left(\mathrm{kg} / \mathrm{m}^{2}\right)$ & $25.8 \pm 3.2$ & $26.3 \pm 3.3$ & 0.009 & $26.1 \pm 3.2$ & $26.1 \pm 3.2$ & 0.990 \\
\hline Hypertension, n (\%) & $696(75.8)$ & $585(82.5)$ & 0.001 & $530(80.3)$ & $537(81.4)$ & 0.624 \\
\hline Diabetes mellitus, n (\%) & $510(55.6)$ & $408(57.5)$ & 0.422 & $372(56.4)$ & $379(57.4)$ & 0.697 \\
\hline Previous angina, n (\%) & 844(91.9) & $659(92.9)$ & 0.447 & 615(93.2) & 614(93.0) & 0.913 \\
\hline Previous MI, n (\%) & 162(17.6) & $85(12.0)$ & 0.002 & $84(12.7)$ & $85(12.9)$ & 0.934 \\
\hline Previous PCl, n (\%) & $271(29.5)$ & 196(27.6) & 0.407 & $178(27.0)$ & 182(27.6) & 0.805 \\
\hline Previous HF, n (\%) & $34(3.7)$ & $15(2.1)$ & 0.063 & $14(2.1)$ & $15(2.3)$ & 0.851 \\
\hline Previous CABG, n (\%) & $23(2.5)$ & $10(1.4)$ & 0.120 & $10(1.5)$ & $10(1.5)$ & 1.000 \\
\hline Previous CKD, n (\%) & $24(2.6)$ & $18(2.5)$ & 0.924 & $17(2.6)$ & $16(2.4)$ & 0.860 \\
\hline Previous COPD, n (\%) & $14(1.5)$ & $18(2.5)$ & 0.144 & $12(1.8)$ & $13(2.0)$ & 0.840 \\
\hline Previous PVD, n (\%) & $11(1.2)$ & $11(1.6)$ & 0.541 & $10(1.5)$ & $8(1.2)$ & 0.635 \\
\hline Current smokers, n (\%) & $366(39.9)$ & 278(39.2) & 0.787 & $270(40.9)$ & $259(39.2)$ & 0.537 \\
\hline LVEF (\%) & $61.9 \pm 5.5$ & $62.4 \pm 4.8$ & 0.073 & $62.4 \pm 4.9$ & $62.4 \pm 4.9$ & 0.977 \\
\hline SBP $(m m H g)$ & $\begin{array}{l}139.1 \pm \\
19.1\end{array}$ & $\begin{array}{l}138.2 \pm \\
19.2\end{array}$ & 0.332 & $\begin{array}{l}138.9 \pm \\
19.2\end{array}$ & $\begin{array}{l}138.5 \pm \\
19.1\end{array}$ & 0.707 \\
\hline $\mathrm{DBP}(\mathrm{mmHg})$ & $\begin{array}{l}80.4 \pm \\
12.0\end{array}$ & $\begin{array}{l}79.2 \pm \\
11.2\end{array}$ & 0.054 & $\begin{array}{l}79.8 \pm \\
11.8\end{array}$ & $\begin{array}{l}79.6 \pm \\
11.2\end{array}$ & 0.831 \\
\hline \multicolumn{7}{|l|}{ Laboratory indicators } \\
\hline $\begin{array}{l}\text { Serum creatinine } \\
\text { (umol/L) }\end{array}$ & $\begin{array}{l}68.7 \pm \\
18.4\end{array}$ & $\begin{array}{l}68.4 \pm \\
16.8\end{array}$ & 0.777 & $\begin{array}{l}68.7 \pm \\
18.3\end{array}$ & $\begin{array}{l}68.3 \pm \\
16.8\end{array}$ & 0.641 \\
\hline
\end{tabular}

Abbreviations: ACEI, angiotensin-converting enzyme inhibitor; ARB, angiotensin receptor blocker; BMI, body mass index; MI, myocardial infarction; $\mathrm{PCl}$, percutaneous coronary intervention; $\mathrm{HF}$, heart failure; CABG, coronary artery bypass graft; CKD, chronic kidney disease; COPD, chronic obstructive pulmonary disease; PVD, peripheral vascular disease; LVEF, left ventricular ejection fraction; SBP, systolic blood pressure; DBP, diastolic blood pressure; HDL, high-density lipoprotein; LDL, low-density lipoprotein 


\begin{tabular}{|c|c|c|c|c|c|c|}
\hline & $\begin{array}{l}\text { ACEI } \\
(n=918)\end{array}$ & $\begin{array}{l}\text { ARB } \\
(n=709)\end{array}$ & $\mathbf{P}$ & $\begin{array}{l}\text { ACEI } \\
(n=660)\end{array}$ & $\begin{array}{l}\text { ARB } \\
(n=660)\end{array}$ & $\mathbf{P}$ \\
\hline Blood glucose (mmol/L) & $7.9 \pm 2.8$ & $7.8 \pm 2.9$ & 0.760 & $7.9 \pm 2.8$ & $7.8 \pm 2.9$ & 0.736 \\
\hline $\begin{array}{l}\text { Total cholesterol } \\
(\mathrm{mmol} / \mathrm{L})\end{array}$ & $4.5 \pm 1.3$ & $4.5 \pm 1.3$ & 0.813 & $4.5 \pm 1.4$ & $4.5 \pm 1.3$ & 0.793 \\
\hline Triglyceride $(\mathrm{mmol} / \mathrm{L})$ & $1.7 \pm 1.3$ & $1.8 \pm 1.1$ & 0.555 & $1.8 \pm 1.4$ & $1.8 \pm 1.2$ & 0.920 \\
\hline $\begin{array}{l}\text { HDL cholesterol } \\
(\mathrm{mmol} / \mathrm{L})\end{array}$ & $1.1 \pm 0.3$ & $1.1 \pm 0.3$ & 0.590 & $1.1 \pm 0.3$ & $1.1 \pm 0.3$ & 0.945 \\
\hline LDL cholesterol (mmol/L) & $2.7 \pm 1.0$ & $2.7 \pm 0.9$ & 0.952 & $2.7 \pm 1.0$ & $2.7 \pm 0.9$ & 0.890 \\
\hline Haemoglobin(g/L) & $\begin{array}{l}137.1 \pm \\
15.7\end{array}$ & $\begin{array}{l}136.6 \pm \\
15.5\end{array}$ & 0.471 & $\begin{array}{l}136.8 \pm \\
15.4\end{array}$ & $\begin{array}{l}136.6 \pm \\
15.5\end{array}$ & 0.784 \\
\hline
\end{tabular}

Discharge medication

\begin{tabular}{|c|c|c|c|c|c|c|}
\hline Aspirin, n (\%) & 915(99.7) & $706(99.6)$ & 1.000 & 658(99.7) & $657(99.5)$ & 1.000 \\
\hline Clopidogrel, n (\%) & 730(79.5) & $610(86.0)$ & 0.001 & $554(83.9)$ & $564(85.5)$ & 0.445 \\
\hline Ticagrelor, n (\%) & 188(20.5) & $99(14.0)$ & 0.001 & 106(16.1) & $96(14.5)$ & 0.445 \\
\hline $\begin{array}{l}\text { Lipid-lowering agents, } n \\
(\%)\end{array}$ & $888(96.7)$ & $685(96.6)$ & 0.896 & $637(96.5)$ & $640(97.0)$ & 0.642 \\
\hline Beta-blockers, n (\%) & $698(76.0)$ & $472(66.6)$ & 0.000 & $471(71.4)$ & $456(69.1)$ & 0.367 \\
\hline \multicolumn{7}{|c|}{ Coronary angiography characteristics } \\
\hline \multicolumn{7}{|l|}{ Infarct-related artery } \\
\hline Left main, n (\%) & $23(2.5)$ & $12(1.7)$ & 0.262 & $12(1.8)$ & $12(1.8)$ & 1.000 \\
\hline $\begin{array}{l}\text { Left anterior descending, } \\
\mathrm{n}(\%)\end{array}$ & $479(52.2)$ & $367(51.8)$ & 0.868 & $346(52.4)$ & $344(52.1)$ & 0.912 \\
\hline Left circumflex, n (\%) & 232(25.3) & 199(28.1) & 0.205 & $177(26.8)$ & $182(27.6)$ & 0.757 \\
\hline Right coronary, n (\%) & $324(35.3)$ & $254(35.8)$ & 0.824 & 237(35.9) & $232(35.2)$ & 0.774 \\
\hline 2-vessel, n (\%) & $114(12.4)$ & $109(15.4)$ & 0.086 & $96(14.5)$ & $96(14.5)$ & 1.000 \\
\hline 3-vessel, n (\%) & $1(0.1)$ & $1(0.1)$ & 0.855 & $1(0.2)$ & $1(0.2)$ & 1.000 \\
\hline
\end{tabular}

Abbreviations: ACEI, angiotensin-converting enzyme inhibitor; ARB, angiotensin receptor blocker; $\mathrm{BMI}$, body mass index; MI, myocardial infarction; PCl, percutaneous coronary intervention; HF, heart failure; CABG, coronary artery bypass graft; CKD, chronic kidney disease; COPD, chronic obstructive pulmonary disease; PVD, peripheral vascular disease; LVEF, left ventricular ejection fraction; SBP, systolic blood pressure; DBP, diastolic blood pressure; HDL, high-density lipoprotein; LDL, low-density lipoprotein 


\begin{tabular}{|c|c|c|c|c|c|c|}
\hline \multirow[t]{2}{*}{ Variables } & \multicolumn{3}{|c|}{ All patients } & \multicolumn{3}{|c|}{$\begin{array}{l}\text { Propensity score matching } \\
\text { patients }\end{array}$} \\
\hline & $\begin{array}{l}\text { ACEI } \\
(n=918)\end{array}$ & $\begin{array}{l}\text { ARB } \\
(n=709)\end{array}$ & $\mathbf{P}$ & $\begin{array}{l}\text { ACEI } \\
(n=660)\end{array}$ & $\begin{array}{l}\text { ARB } \\
(n=660)\end{array}$ & $\mathbf{P}$ \\
\hline Number of stents & $1.4 \pm 0.6$ & $1.4 \pm 0.6$ & 0.912 & $1.4 \pm 0.6$ & $1.4 \pm 0.6$ & 0.828 \\
\hline \multicolumn{7}{|c|}{$\begin{array}{l}\text { Abbreviations: ACEI, angiotensin-converting enzyme inhibitor; ARB, angiotensin receptor blocker; } B M I \text {, } \\
\text { body mass index; MI, myocardial infarction; PCl, percutaneous coronary intervention; HF, heart failure; } \\
\text { CABG, coronary artery bypass graft; CKD, chronic kidney disease; COPD, chronic obstructive } \\
\text { pulmonary disease; PVD, peripheral vascular disease; LVEF, left ventricular ejection fraction; SBP, } \\
\text { systolic blood pressure; DBP, diastolic blood pressure; HDL, high-density lipoprotein; LDL, low-density } \\
\text { lipoprotein }\end{array}$} \\
\hline
\end{tabular}

In comparison to patients prescribed ACEls, the average BMI $\left(26.3 \pm 3.3 \mathrm{~kg} / \mathrm{m}^{2} \mathrm{vs} .25 .8 \pm 3.2 \mathrm{~kg} / \mathrm{m}^{2}\right.$, $P=0.009)$ and the number of patients who had hypertension ( $82.5 \%$ vs. $75.8 \%, P=0.001)$ were higher in patients prescribed ARBs. In contrast, the ACEl group showed a higher prevalence of a previous history of MI (17.6\% vs. $12.0 \%, P=0.002)$. In addition, we found that prescription rates for ticagrelor $(20.5 \%$ vs. $14.0 \%, P=0.001)$ and beta-blockers $(76.0 \%$ vs. $66.6 \%, P=0.000)$ were higher in the ACEl group at discharge. In contrast, the use of clopidogrel $(86.0 \%$ vs. $79.5 \%, P=0.001)$ was more frequent in the ARB group. Laboratory indicators and coronary angiography characteristics were comparable in both groups.

After matching, potential confounding biases derived from differences in baseline levels were considered in excellent balance between the two groups.

\section{Clinical outcomes}

Clinical outcomes by the Kaplan-Meier method and the multivariable Cox regression analysis with a follow-up period of 13 months between both groups are demonstrated in Table 2 and Fig. 2 . 
Table 2

Clinical outcomes by the Kaplan-Meier method and multivariable Cox regression analysis

Outcomes

Cumulative events at 13 months

ACEI ARB Log-rank Hazard ratio $(95 \% \mathrm{Cl}) \quad \mathrm{P}$

All Patients

$\begin{array}{llllll}\text { MACCEs } & 33(3.6 \%) & 21(3.0 \%) & 0.473 & 0.860(0.494-1.495) & 0.593 \\ \text { All-cause death } & 14(1.5 \%) & 4(0.6 \%) & 0.066 & 0.385(0.124-1.191) & 0.097 \\ \text { Non-fatal MI } & 3(0.3 \%) & 5(0.7 \%) & 0.285 & 2.540(0.592-10.898) & 0.210 \\ \text { Stroke } & 3(0.3 \%) & 4(0.6 \%) & 0.473 & 1.718(0.384-7.675) & 0.479 \\ \text { TVR } & 16(1.7 \%) & 12(1.7 \%) & 0.925 & 0.998(0.471-2.116) & 0.997\end{array}$

Propensity score matching patients

$\begin{array}{llllll}\text { MACCEs } & 22(3.3 \%) & 19(2.9 \%) & 0.625 & 0.860(0.465-1.590) & 0.630 \\ \text { All-cause death } & 10(1.5 \%) & 3(0.5 \%) & 0.051 & 0.334(0.090-1.238) & 0.101 \\ \text { Non-fatal MI } & 1(0.2 \%) & 5(0.8 \%) & 0.104 & 4.929(0.576-42.195) & 0.145 \\ \text { Stroke } & 3(0.5 \%) & 3(0.5 \%) & 0.996 & 1.049(0.208-5.290) & 0.954 \\ \text { TVR } & 9(1.4 \%) & 12(1.8 \%) & 0.522 & 1.276(0.537-3.031) & 0.581\end{array}$

Abbreviations: $\mathrm{ACEl}$, angiotensin-converting enzyme inhibitor; $\mathrm{ARB}$, angiotensin receptor blocker; $\mathrm{Cl}$, confidence interval; MACCEs, major adverse cardiovascular and cerebrovascular events; Nonfatal MI, nonfatal myocardial infarction; TVR, target vessel revascularization

The occurrence of MACCEs (3.6\% vs. $3.0 \%$, Log-rank $P=0.473, \mathrm{HR}=0.860,95 \% \mathrm{Cl}: 0.494-1.495, P=0.593$ ), all-cause death (1.5\% vs. 0.6\%, Log-rank $P=0.066, \mathrm{HR}=0.385,95 \% \mathrm{Cl}: 0.124-1.191, P=0.097)$, non-fatal MI ( $0.3 \%$ vs. $0.7 \%$, Log-rank $P=0.285, \mathrm{HR}=2.540,95 \% \mathrm{Cl}$ : $0.592-10.898, P=0.210)$, stroke ( $0.3 \%$ vs. $0.6 \%$, Logrank $P=0.473, \mathrm{HR}=1.718,95 \% \mathrm{Cl}: 0.384-7.675, P=0.479)$ and TVR $(1.7 \%$ vs. $1.7 \%$, Log-rank $P=0.925$, $\mathrm{HR}=0.998,95 \% \mathrm{Cl}: 0.471-2.116, P=0.997)$ did not differ significantly between the two groups.

After PSM, we also found no differences in the incidence of MACCEs (3.3\% vs. 2.9\%, Log-rank $P=0.625$, $\mathrm{HR}=0.860,95 \% \mathrm{Cl}: 0.465-1.590, P=0.630)$, all-cause death (1.5\% vs. $0.5 \%$, Log-rank $P=0.051, \mathrm{HR}=0.334$, $95 \% \mathrm{Cl}: 0.090-1.238, P=0.101)$, non-fatal MI (0.2\% vs. $0.8 \%$, Log-rank $P=0.104, \mathrm{HR}=4.929,95 \% \mathrm{Cl}$ : 0.57642.195, $P=0.145)$, stroke (0.5\% vs. 0.5\%, Log-rank $P=0.996, \mathrm{HR}=1.049,95 \% \mathrm{Cl}: 0.208-5.290, P=0.954)$ and TVR (1.4\% vs. $1.8 \%$, Log-rank $P=0.522, \mathrm{HR}=1.276,95 \% \mathrm{Cl}$ : $0.537-3.031, P=0.581)$ between the ACEl and ARB groups.

Fig. 3 presents subgroup analyses concerning MACCEs in all study populations. There was no obvious difference in prognosis according to the multivariate Cox regression analysis between the two groups. 


\section{Discussion}

Our present research was the first to indicate that there were no differences in MACCEs, all-cause death, nonfatal MI, stroke or TVR between the ACEl and ARB groups in UA patients undergoing successful PCl with preserved left ventricular systolic function. Similarly, we also found no differences in subgroup analyses based on age, sex, risk factors for coronary disease (hypertension and diabetes mellitus), discharge medication (beta-blockers) and coronary angiography characteristics (left anterior descending artery occlusion).

ACEI can decrease mortality and the risk of myocardial infarction in patients who have left ventricular systolic dysfunction ${ }^{[4-6]}$. Therefore, the 2020 European guideline advises that ACEls should be taken into consideration in UA patients with heart failure (HF) with $\mathrm{LVEF}<40 \%$ unless contraindicated, while ARBs are an alternative treatment for patients with ACEl intolerance ${ }^{[7]}$. Nevertheless, presently, the long-term prognosis using ACEls or ARBs is still controversial. In the VALIANT trial ${ }^{[8]}$, valsartan and captopril demonstrated similar effectiveness in reducing death from any cause after acute myocardial infarction (AMI). Similar drug effects were in accordance with our findings. However, only AMI patients who had left ventricular systolic dysfunction in the VALIANT trial were enrolled, which made the conclusions less conclusive. In the ONTARGET trial[ ${ }^{[9]}$, telmisartan also showed no significant difference in cardiac outcomes compared to ramipril in diabetes mellitus or vascular disease patients, who were not associated with HF. However, the small proportion of UA patients (14.9\%) and the lack of LVEF data in the ONTARGET trial made the results not meet our targeted population. In addition, the OPTIMAAL trial ${ }^{[10]}$ also showed no differences in the incidence of deaths (18\% vs. $16 \%, \mathrm{HR}=1.13,95 \% \mathrm{Cl}: 0.99-1.28, P=0.07)$, cardiac death (CD) (9\% vs. $7 \%, \mathrm{HR}=1.19,95 \% \mathrm{Cl}$ : 0.98-1.43, $P=0.07)$, non-fatal reinfarction ( $14 \% \mathrm{vs.} 14 \%$, $\mathrm{HR}=1.03,95 \% \mathrm{Cl}: 0.89-1.18, P=0.72)$ and all-cause hospital admission (66\% vs. $65 \%, \mathrm{HR}=1.03,95 \% \mathrm{Cl}: 0.97-$ $1.10, P=0.37$ ) between losartan and captopril groups at a median follow-up period of 2.7(0.9) years. Even though comparable cardiovascular risk between two groups, the OPTIMAAL trial recommended that ACEI should be considered as preferred therapy in patients who had a high risk AMI.

It was recently pointed out that patients prescribed ACEls had more improved survival than patients prescribed ARBs in a period of 5 years after $\mathrm{AMI}(\mathrm{HR}=0.53,95 \% \mathrm{Cl}: 0.38-0.74, P<0.001)^{[11]}$.

ACEls and ARBs have their respective mechanisms of action that may contribute to differences in longterm prognosis between the two groups ${ }^{[12-17]}$. ACEl has been shown to decrease the risk of death and $\mathrm{MI}$ in patients with hypertension, diabetes mellitus and HF. Conversely, ARB does not seem to decrease the risk of death or MI. This is because ACEls have cardiovascular benefits independent of antihypertensive effects, which are absent in ARBs ${ }^{[12,13]}$. ACEl inhibits angiotensin converting enzyme (ACE) and consequently reduces the production of angiotensin II. ACEI also suppresses bradykinin breakdown into inactive peptides, whereas bradykinin has many benefits, such as the improvement of endothelial function and ischaemic preconditioning, delaying the development of atherosclerosis, vasodilation and stimulation of nitric oxide $1^{[14-16]}$. ARB blocks selectivity for the angiotensin II type 1 (AT1) receptor, which 
contributes to a compensatory elevation of angiotensin II levels and the activation of the angiotensin II type 2 (AT2) receptor. Moreover, the AT2 receptor causes detrimental effects, including instability and rupture of plaques, thrombosis, inflammation and myocyte apoptosis ${ }^{[17]}$.

In short, current European guidelines do not fully encompass the longer-term use of ACEls or ARBs in UA patients who have preserved left ventricular systolic function. Since the percentage of patients with LVEF $\geq 40 \%$ is higher than that of patients with LVEF $<40 \%$ after $U A^{[18]}$, it is essential to investigate the effects of ACEIs/ARBs on long-term prognosis. For this reason, we compared clinical outcomes between ACEI or ARB treatment in UA patients undergoing successful PCI with preserved left ventricular systolic function.

Several retrospective observational studies have recently described comparable cardiovascular risk between ACEI/ARB treatment in UA patients with preserved left ventricular systolic function after PCl. Raposeiras et al. ${ }^{[18]}$ reported that patients who had non-ST elevation ACS with LVEF $\geq 40 \%$ did not appear to benefit from ACEI/ARB in reducing mortality. However, this study did not evaluate the effects of ACEls and ARBs separately. Cespon et al. ${ }^{[19]}$ also focused on a non-ST elevation ACS population with LVEF $\geq 40 \%$ to assess whether the selection between ACEls and ARBs could contribute to differences in long-term prognosis. They found that there were no differences in combined events (all-cause death, AMI and $\mathrm{HF})(\mathrm{HR}=1.03,95 \% \mathrm{Cl}$ : 0.85-1.24, $P=0.796)$, AMI (HR=1.03, 95\% Cl: 0.75-1.43, $P=0.839)$ and HF $(\mathrm{HR}=1.04,95 \% \mathrm{Cl}: 0.81-1.34, P=0.768)$ between the ACEl and ARB groups after the follow-up period (median follow-up: 3.6 \pm 2 .1years). Their findings on the lack of differences in prognosis were consistent with ours. Ann et al. ${ }^{[20]}$ divided the study population with CHD into AMI $(n=21747)$ and angina $(n=28708)$. They allocated those patients into two groups, the ACEI and ARB groups, based on discharge medications. After PSM, they found that the occurrence of all-cause death ( $\mathrm{HR}=1.113,95 \% \mathrm{Cl}$ : 0.986 $1.257, P=0.084$ ) was not significantly different in the angina group, with a median follow-up of 2.2 years. Nevertheless, neither of the above study populations ${ }^{[18-20]}$ were restricted to patients with UA.

Our study is the first to examine the longer-term use of ACEI or ARB treatment in an East Asian population with UA with preserved left ventricular systolic function after $\mathrm{PCl}$, which manifests a real clinical world outlook. Prognoses were comparable between ACEl or ARB treatment according to our final conclusion. Hence, we think that our study may not only increase indications and prescriptions of ARBs but also provide important references for cardiologists about the selection of renin-angiotensin-aldosterone system (RAAS) inhibitors after PCI. However, further prospective, high-quality, large-sample randomized controlled trials are required to evaluate the conclusion.

There were many limitations during our study. First, our study was a single-centre retrospective study with a small sample size, which might cause data loss and selection bias. Second, our study did not collect specific data concerning the species and dose of ACEls and ARBs. Third, we divided the study population by postdischarge medication, and we do not know how long patients had been taking their medications after discharge. Such confounding factors might significantly influence the reliability of the outcomes. Fourth, the selection of RAAS inhibitors after PCI was at the discretion of the cardiologists. Finally, even 
though we performed PSM to adjust for possible confounding baseline factors, a large-sample prospective randomized controlled trial is required to corroborate our findings.

\section{Conclusion}

No clear differences in MACCEs, all-cause death, nonfatal MI, stroke or TVR were observed between the ACEl and ARB groups during a 13-month follow-up period. Thus, we consider that prognoses are comparable between ACEI or ARB treatment in UA patients who have preserved left ventricular systolic function after $\mathrm{PCl}$. To further confirm our results, prospective and large-sample randomized controlled trials are needed.

\section{Abbreviations}

UA: unstable angina; ACS: acute coronary syndrome; PCI: percutaneous coronary intervention; ACEl: angiotensin-converting enzyme inhibitor; LVEF: left ventricular ejection fraction; ARB: angiotensin receptor blocker; CHD: coronary heart disease; CAG: coronary angiography; MACCEs: major adverse cardiovascular and cerebrovascular events; MI: myocardial infarction; TVR: target vessel revascularization; PSM: propensity score matching; HR: hazard ratio; Cl: confidence interval; HF: heart failure; AMI: acute myocardial infarction; CD: cardiac death; ACE: angiotensin-converting enzyme; AT1: angiotensin II type 1; AT2: angiotensin II type 2; RAAS: renin-angiotensin-aldosterone system.

\section{Declarations}

\section{Ethics approval and consent to participate}

All patients gave their written informed consent. This research was granted approval by the ethics committee of TEDA International Cardiovascular Hospital ([2020]-1021-1) and was conducted according to the Declaration of Helsinki.

\section{Consent for publication}

Not applicable.

\section{Availability of data and materials}

The datasets used during the current study are available from the corresponding author upon reasonable request.

\section{Competing interests}

The authors declare that they have no competing interests.

\section{Funding}


This study was supported by the Tianjin Science and Technology Project (16ZXMJSY00080).

\section{Authors' contributions}

LL conceived the study and conducted the data analysis. JX was involved in the procedure and wrote the manuscript. WL applied for funding, supervised the study and revised the manuscript. All authors read and approved the final manuscript.

\section{Acknowledgements}

The authors thank all participants for their contributions.

\section{Author details}

${ }^{1}$ Department of Cardiology I, TEDA International Cardiovascular Hospital, Tianjin 300457, China.

\section{References}

1. Yeghiazarians Y, Braunstein JB, Askari A, Stone PH. Unstable angina pectoris. N Engl J Med. 2000;342:101-14.

2. Braunwald E. Unstable angina and non-ST elevation myocardial infarction. Am J Respir Crit Care Med. 2012;185:924-32.

3. Smith SC, Jr., Benjamin EJ, Bonow RO, Braun LT, Creager MA, Franklin BA, et al. AHA/ACCF secondary prevention and risk reduction therapy for patients with coronary and other atherosclerotic vascular disease: 2011 update: A guideline from the american heart association and american college of cardiology foundation. Circulation. 2011;124:2458-73.

4. Investigators S, Yusuf S, Pitt B, Davis CE, Hood WB, Cohn JN. Effect of enalapril on survival in patients with reduced left ventricular ejection fractions and congestive heart failure. $\mathrm{N}$ Engl $\mathrm{J}$ Med. 1991;325:293-302.

5. Pfeffer MA, Braunwald E, Moye LA, Basta L, Brown EJ, Jr., Cuddy TE, et al. Effect of captopril on mortality and morbidity in patients with left ventricular dysfunction after myocardial infarction. Results of the survival and ventricular enlargement trial. The save investigators. $\mathrm{N}$ Engl $\mathrm{J}$ Med. 1992;327:669-77.

6. Flather MD, Yusuf S, Kober L, Pfeffer M, Hall A, Murray G, et al. Long-term ACE-inhibitor therapy in patients with heart failure or left-ventricular dysfunction: A systematic overview of data from individual patients. ACE-inhibitor myocardial infarction collaborative group. Lancet. 2000;355:157581.

7. Collet JP, Thiele H, Barbato E, Barthelemy O, Bauersachs J, Bhatt DL, et al. 2020 ESC guidelines for the management of acute coronary syndromes in patients presenting without persistent ST-segment elevation. Eur Heart J. 2021;42:1289-367. 
8. Pfeffer MA, McMurray JJ, Velazquez EJ, Rouleau JL, Kober L, Maggioni AP, et al. Valsartan, captopril, or both in myocardial infarction complicated by heart failure, left ventricular dysfunction, or both. $\mathrm{N}$ Engl J Med. 2003;349:1893-906.

9. Investigators O, Yusuf S, Teo KK, Pogue J, Dyal L, Copland I, et al. Telmisartan, ramipril, or both in patients at high risk for vascular events. N Engl J Med. 2008;358:1547-59.

10. Dickstein K, Kjekshus J, Group OSCotOS. Effects of losartan and captopril on mortality and morbidity in high-risk patients after acute myocardial infarction: The OPTIMAAL randomised trial. Optimal trial in myocardial infarction with angiotensin ii antagonist losartan. Lancet. 2002;360:752-60.

11. Hara M, Sakata Y, Nakatani D, Suna S, Usami M, Matsumoto S, et al. Comparison of 5-year survival after acute myocardial infarction using angiotensin-converting enzyme inhibitor versus angiotensin ii receptor blocker. Am J Cardiol. 2014;114:1-8.

12. Strauss MH, Hall AS. The divergent cardiovascular effects of angiotensin converting enzyme inhibitors and angiotensin receptor blockers on myocardial infarction and death. Prog Cardiovasc Dis. 2016;58:473-82.

13. Blood Pressure Lowering Treatment Trialists C, Turnbull F, Neal B, Pfeffer M, Kostis J, Algert C, et al. Blood pressure-dependent and independent effects of agents that inhibit the renin-angiotensin system. J Hypertens. 2007;25:951-8.

14. Probstfield JL, O'Brien KD. Progression of cardiovascular damage: The role of renin-angiotensin system blockade. Am J Cardiol. 2010;105:10A-20A.

15. Dezsi CA, Szentes V. Effects of angiotensin-converting enzyme inhibitors and angiotensin receptor blockers on prothrombotic processes and myocardial infarction risk. Am J Cardiovasc Drugs. 2016;16:399-406.

16. Effect of ramipril on mortality and morbidity of survivors of acute myocardial infarction with clinical evidence of heart failure. The acute infarction ramipril efficacy (AIRE) study investigators. Lancet. 1993;342:821-8.

17. Strauss MH, Hall AS. Angiotensin receptor blockers may increase risk of myocardial infarction: Unraveling the ARB-MI paradox. Circulation. 2006;114:838-54.

18. Raposeiras-Roubin S, Abu-Assi E, Cespon-Fernandez M, Ibanez B, Garcia-Ruiz JM, D'Ascenzo F, et al. Impact of renin-angiotensin system blockade on the prognosis of acute coronary syndrome based on left ventricular ejection fraction. Rev Esp Cardiol (Engl Ed). 2020;73:114-22.

19. Cespon-Fernandez M, Raposeiras-Roubin S, Abu-Assi E, Pousa IM, Queija BC, Paz RJC, et al. Angiotensin-converting enzyme inhibitors versus angiotensin ii receptor blockers in acute coronary syndrome and preserved ventricular ejection fraction. Angiology. 2020;71:886-93.

20. Ann SH, Strauss MH, Park GM, Han S, Yang Y, Kim YG, et al. Comparison between angiotensinconverting enzyme inhibitor and angiotensin receptor blocker after percutaneous coronary intervention. Int J Cardiol. 2020;306:35-41.

\section{Figures}


3812 CHD patients undergoing PCI in TEDA International Cardiovascular Hospital (from October 2016 to September 2017)

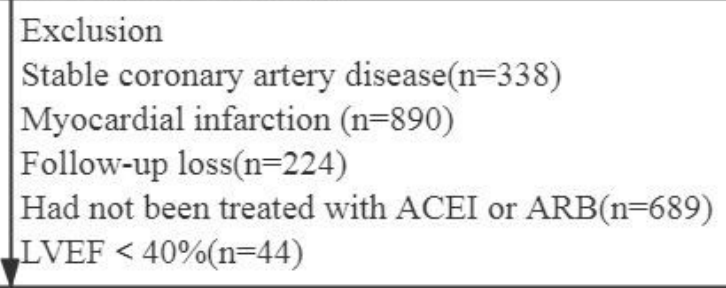

Finally, 1627 UA patients with preserved left ventricular systolic function after PCI and received ACEI or ARB

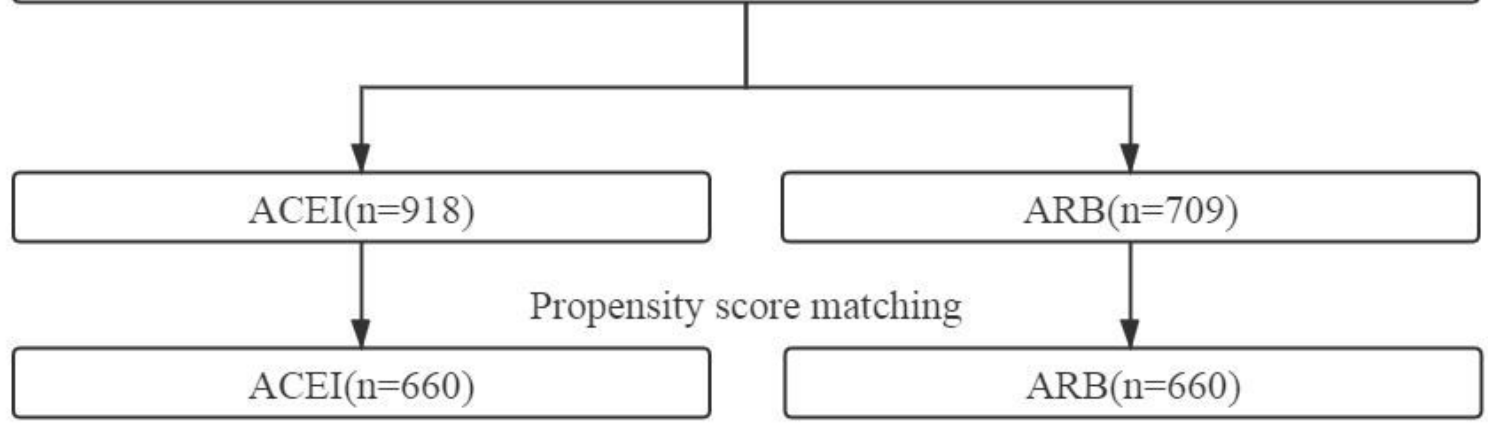

\section{Figure 1}

The study population flowchart. CHD, coronary heart disease; $\mathrm{PCl}$, percutaneous coronary intervention; ACEl, angiotensin-converting enzyme inhibitor; ARB, angiotensin receptor blocker; LVEF, left ventricular ejection fraction; UA, unstable angina 
a

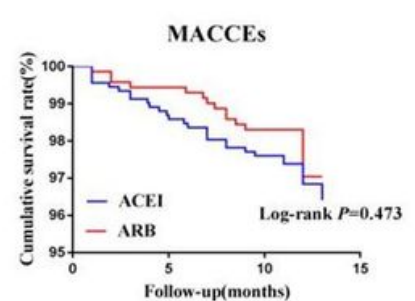

c All study population

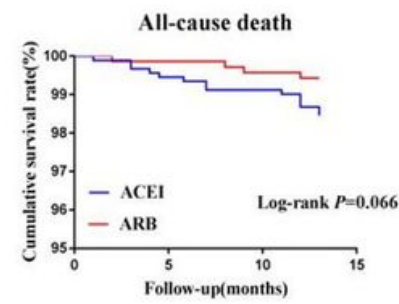

e

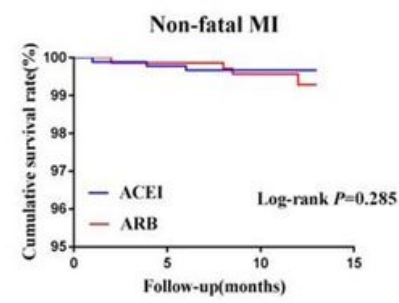

b PSM patients

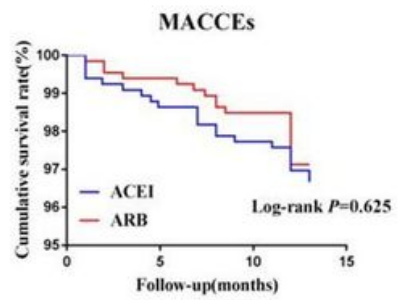

d PSM patients

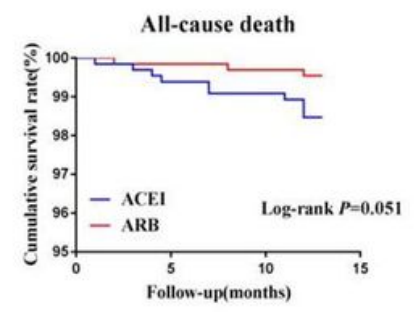

g All study population

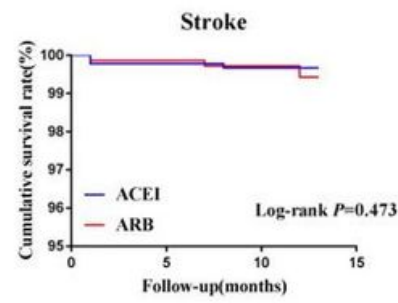

i All study population

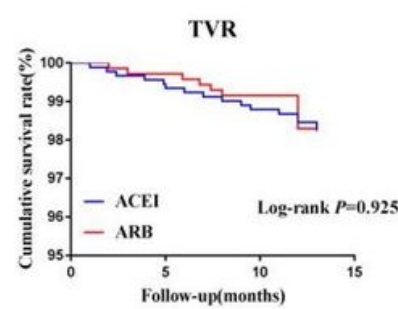

h PSM patients

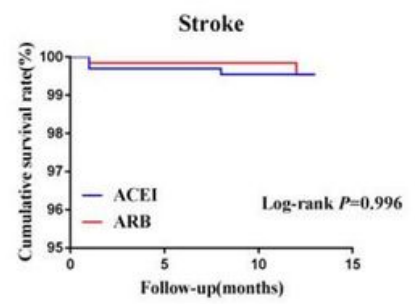

j PSM patients

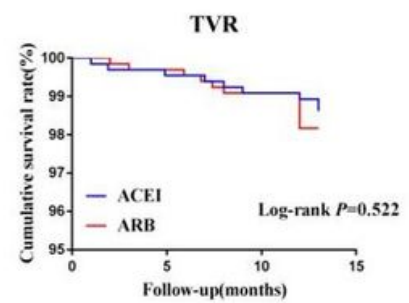

\section{Figure 2}

Survival curves for the all study population $(a, c, e, g, i)$ and PSM patients $(b, d, f, h, j)$. PSM, propensity score matching; MACCEs, major adverse cardiovascular and cerebrovascular events; nonfatal Ml, nonfatal myocardial infarction; TVR, target vessel revascularization; ACEl, angiotensin-converting enzyme inhibitor; ARB, angiotensin receptor blocker 


\begin{tabular}{|c|c|c|c|c|}
\hline Variable & No. of patients & MACCEs & Hazard ratio $(95 \%$ CI) & $\boldsymbol{P}$ \\
\hline \multicolumn{5}{|c|}{ Age (years) } \\
\hline$\geq 65$ & 708 & & $0.798(0.358-1.776)$ & 0.580 \\
\hline$<65$ & 919 & & $0.831(0.393-1.760)$ & 0.629 \\
\hline \multicolumn{5}{|l|}{ Gender } \\
\hline Men & 969 & & $0.870(0.445-1.700)$ & 0.684 \\
\hline Women & 658 & & $0.750(0.291-1.934)$ & 0.551 \\
\hline \multicolumn{5}{|c|}{ Hypertension } \\
\hline Yes & 1281 & & $0.985(0.544-1.783)$ & 0.960 \\
\hline No & 346 & & $0.197(0.025-1.555)$ & 0.123 \\
\hline \multicolumn{5}{|c|}{ Diabetes mellitus } \\
\hline Yes & 918 & & $0.671(0.342-1.318)$ & 0.247 \\
\hline No & 709 & & $1.201(0.464-3.114)$ & 0.706 \\
\hline \multicolumn{5}{|c|}{ Beta-blockers } \\
\hline Yes & 1170 & & $0.869(0.468-1.613)$ & 0.657 \\
\hline No & 457 & & $0.775(0.237-2.540)$ & 0.674 \\
\hline \multicolumn{5}{|c|}{ LAD occlusion } \\
\hline Yes & 846 & & $1.038(0.486-2.217)$ & 0.924 \\
\hline No & 781 & & $0.637(0.286-1.419)$ & 0.270 \\
\hline
\end{tabular}

Favor ARB Favor ACEI

\section{Figure 3}

Subgroup analyses concerning MACCEs in all study populations. MACCEs, major adverse cardiovascular and cerebrovascular events; $\mathrm{Cl}$, confidence interval; LAD, left anterior descending; ACEl, angiotensinconverting enzyme inhibitor; ARB, angiotensin receptor blocker 